\title{
Memories at War or Memories in Continuum: Challenging the Borders of Memory in Seven Jewish Children: A Play for Gaza
}

Sahar Elmougy*

Seven Jewish Children: A Play for Gaza was written in response to Operation Cast Lead, the Israeli military offensive launched on $27^{\text {th }}$ December 2008 in the Gaza strip. Some 1,400 Palestinians and thirteen Israelis were killed, and tens of thousands of Palestinians were left homeless. The United Nations fact-finding mission on the Gaza conflict states that "the conduct of the Israeli armed forces constitutes grave breaches of the Fourth Geneva Convention with respect to willful killings and willfully causing great suffering to protected persons and, as such, give rise to individual criminal responsibility" (UNHRC 20). Written days after the beginning of the Israeli military offensive, Seven Jewish Children was first performed in London's Royal Court Theater on $6^{\text {th }}$ February 2009. After that, it was performed across the UK, the US, Israel, and around the world.

The very short play, eight pages in print and less than ten minutes in performance, features Jewish and Israeli characters who are discussing what to tell/ not to tell Jewish girls at different historical moments in Jewish and Israeli history. Skimming through sixty years in a few minutes, the seven scenes of the play begin with the Holocaust and end with the military offensive in Gaza. The moral dilemmas of the Jewish and Israeli characters surface as they try to decide what to tell or not to tell the young Jewish girls of the family who are never present on stage. Since the stage directions do not assign utterances to specific characters, the scenes of the play could be given by many characters with different opinions and positions, or by one character suffering an inner conflict as shown in the imperative form dominating most of the lines: "tell her/do not tell her."

Upon its release in London's Royal Theater and the subsequent video of the play produced by The Guardian (2009), Seven Jewish Children led to a furor. Eliciting praise from critics like Michael Billington, who hailed the play as an example of "theater's power to heighten consciousness and articulate moral

\footnotetext{
* Lecturer in the Department of English Language and Literature, Faculty of Arts, Cairo University.

Cairo Studies in English 2021(1): https://cse.journals.ekb.eg/
} 
outrage" (Billington 2009), other critics expressed anger and leveled accusations. Christopher Hart of The Times of London called the play a "dishonest and grossly anti-Israeli rant" and The Spectator believed it to be an "open incitement to hatred" and a "ten-minute blood libel" (Rocamora 2009). Jeffrey Goldberg's headline in The Atlantic ran "Caryl Churchill Advances Demonization of Jews" (Goldberg 2009) and Howard Jacobson in The Independent accused the play of anti-Semitism (Jacobson 2009). Sixty-five Jewish leaders co-signed a letter to the Daily Telegraph, denouncing the play as historically inaccurate (Rocamora 2009). The play has also elicited a number of responses by playwrights who believed Seven Jewish Children to be one-sided and biased towards the Palestinians (Rocamora 2009).

By juxtaposing the collective memories of the Jews/Israelis and the Palestinians, Churchill employs a politics of memory different from the predominant mode which elevates the Holocaust memory to a pedestal where any comparisons or equations are perceived as an unforgivable offense. An examination of the two modes of memory would help explain the reasons behind the aggressive attack on the play as well as the kind of intervention Seven Jewish Children attempts.

\section{On the Different Modes of Memory}

Memory is the past made present. Attempting to define collective memory, Michael Rothberg (2009) takes Richard Terdimen's "useful minimalist definition" (13) as a springboard. Rothberg believes that this definition of memory has two main corollaries. First, since memory makes the past present, it is a contemporary phenomenon. While it engages with the past, it does so from the vantage point of the here and now. Second, memory entails work, working through, labour, or action (13-14). How one collective memory matures and moves to the center of attention is a process which a) happens in the present and b) requires time for the construction of the memory as well as the labor of many agents, including the intellectuals and writers. Rothberg explains that with very few exceptions, collective memories come into being and become established by excluding, belittling and/or discrediting other collective memories (13). Realizing this mode as the predominant politics of memory, Rothberg (2009) points out the need for a "comparative thinking" which "is not afraid to traverse sacrosanct borders of ethnicities and era" (17). One collective memory, he argues, could be constructed through depicting its interconnectedness with other narratives of suffering. Believing the conceptual framework through which commentators and ordinary citizens have addressed the relationship between 
memory, identity, and violence to be dominated by competition over scarce resources, Rothberg (2009) suggests an understanding of "memory as multidirectional: as subject to ongoing negotiation, cross-referencing, and borrowing; as productive and not privative" (13).

In Multidirectional Memory: Remembering the Holocaust in the Age of Decolonization, Rothberg argues that the history of the Holocaust memory and the curve it had taken from the post WWII years to the last decades of the twentieth Century throws light on the two modes of memory: the multidirectional and the competitive. The multidirectional memory exists in the post WWII years when the memory of the Holocaust was in its earliest phase of construction. In the 1950s and 1960s, the Holocaust was seen in conjunction with other histories of violence, such as slavery in America and the Algerian War of Independence. As it was coming into prominence, the memory of the Holocaust helped throw light on other histories of genocide (Rothberg 2009, 15). However, when the Holocaust becomes an established memory in the last decades of the Twentieth Century, a competitive mode of memory prevails. Perceived as a threat to the Holocaust memory of victimhood, the Palestinian memory of exile and displacement is elbowed out by proponents of the memory of the Holocaust.

Undertaking the task of re-narrating the early postwar period, Rothberg notes "that the emergence of collective memory of the Nazi genocide in the 1950s and 1960s takes place in a punctual dialogue with ongoing processes of decolonization and civil rights struggle and their modes of coming to terms with colonialism, slavery, and racism" (Rothberg 2009, 26). Among the early texts which contributed to the construction of the Holocaust memory is W. E. B. Du Bois' article "The Negro and the Warsaw Ghetto." Visiting the Warsaw Ghetto in 1949, the African American intellectual and activist revises his idea of race, specifically his concept of the "double consciousness" (being African and American simultaneously):

[T] he problem of slavery, emancipation, and caste in the United States was no longer in my mind a separate and unique thing as I had so long conceived it. It was not even solely a matter of color and physical and racial characteristics, which was particularly a hard thing for me to learn, since for a lifetime the color line had been a real and efficient cause of misery [...]. The race problem in which I was interested cut across lines of color and physique and belief and status and was a matter of cultural patterns, perverted teaching and 
human hate and prejudice, which reached all sorts of people and caused endless evil to all men. (quoted in Rothberg 2011, 527)

A multidirectional sensibility is evident in Du Bois' article which was published at a time when neither literature on the Holocaust nor even its name had existed yet. He expresses solidarity with the victims while realizing the relationality of the different histories of racial violence. Noting a connection between the two histories of the Jews and American slaves, he also realizes they are asymmetrical. Du Bois allows his understanding of the Jewish suffering to change his "lifetime" perception of the African American issue. It is no longer "separate and unique." This ability to realize the difference between the two pasts while showing no claims for uniqueness for either is an example of multidirectionality (Rothberg 2011, 527)._However, by the last decades of the twentieth century, the Holocaust memory has acquired such uniqueness it has come to be viewed by some as exceeding the boundaries of understanding and as outside history (Rothberg 2009, 16). It has become a reference point for the ultimate evil, so much so that other collective memories either aspire for the same status or feel threatened by it (Rothberg 2009, 16).

Rethinking the conceptualization of collective memory in multicultural and transnational contexts, Rothberg criticizes the dominant politics of collective memory and proposes a different route:

Fully cognizant of the differentials of access and power that mark the public sphere, I nevertheless provide a framework that draws attention to the inevitable dialogical exchange between memory traditions and keeps open the possibility of a more just future of memory. I identify the misrecognition of collective memory as a zero-sum game - instead of an open-ended field of articulation and struggle - as one of the stumbling blocks for a more inclusive renarration of the history of memory and a harnessing of the legacies of violence in the interests of a more egalitarian future. (Rothberg 2009, 26)

Rothberg's theory of multidirectionality challenges the dominant belief in collective memory as "a zero-sum game," a site of competition where the victory of one party means the loss of another. If the construction of a particular collective memory takes place in "an open field of articulation and struggle," then competition and exclusivity might give way to different memories which 
perceive their similitude and connections as well as the asymmetry among them. The positions of winners and losers might change when they realize the multidirectional nature of memory, how the "struggle for recognition is fundamentally unstable and subject to ongoing reversal" (Rothberg 2009, 15). Hence, being a winner "may entail learning from and adopting the rhetoric and images of the other" (Rothberg 2009, 15). In this radically different perspective from the dominant mode of "competitive memory" lies the hope for a future that is less violent and more just (Rothberg 2009, 26).

In his article "From Gaza to Warsaw: Mapping Multidirectional Memory" (2011), Rothberg draws a "schematic" map of the field of memory studies. He arrives at "a four-part distinction in which multidirectional memories are located at the intersection of an axis of comparison as defined by a continuum stretching from equation to differentiation, and an axis of political affect as defined by a continuum stretching from solidarity to competition - Two complex, composite affects (Rothberg 2011, 525). He explains that the two axes of the map, comparison and affect, are "semiautonomous." Hence, the equation cannot be limited to the competitive affect. A combination of equation and solidarity is one possible route in Rothberg's map of memory. He states that "[w]hile the mix of equation and competition concatenates desire and envy into a resistance politics rife with the potential $(2011,535)$ for what Nietzsche called "ressentiment" (i.e. the acting out of one's own suffering on another), the combination of equation and solidarity produces a form of liberal universalism with multicultural accents" the result of which would be "a strong form of empathetic identification" (2011, 535-536).

\section{Challenging the Exclusionary Memory}

The Palestinian-Israeli conflict could be securely (albeit unfortunately) placed in the equation-competition axis of memory. Perceiving themselves as two rivals in a war for survival, their fight is over land as well as memory. The "battle of memories," as Palestinian poet Mahmoud Darwish called it (Darwish 1973, 64), is characterized by exclusion, competition, and trivialization of the other's memory. In their article "Beyond the Destruction of the Other's Collective Memory: Blueprints for a Palestinian/Israeli Dialogue" (2003), Gur-Ze'ev and Pappé state:

In the case of Palestine/Israel, control of the collective memory is part of the internal and external violence each of the rival collectives applies to secure its reconstruction. That is, the way the two sides to 
the conflict construct their collective identity is a dialectical process whose impelling force is the total negation of the Other. Within this dialectic, each side sees itself as a sole victim while totally negating the victimization of the Other. The violence used in order to conquer the centers of power relations and dynamics aims at positioning more 'effectively' one's own narrative, interests, values, symbols, goals and criteria, while at the same time ensuring that those of the Other are marginalized, excluded or destroyed. (93)

In the Palestinian-Israeli battle of memories, each party, entrenched in its own space, turns a blind eye to the other's suffering and victimhood. The war over land and historical rights is paralleled by the arduous construction of a collective memory jeopardized by the presence of the other and his memory. On the one hand, the memory of the Holocaust is used to justify the political and military violence of Israel against the Palestinians. On the other hand, the Palestinian intellectual responses to the Holocaust since the Nakba in 1948 have moved from total denial of the Nazi genocide of the Jews in WWII, to indifference towards it, to acknowledging it happened while minimizing its scale and moral significance, to full acknowledgement of both the event and its universal moral implication as a unique manifestation of human evil (Gur-Ze'ev and Pappe 2003, 94). These stages, which are not sharply demarcated but rather varying, coexisting and fluid, are mostly symptomatic of the competitive memory mode.

Edward Said believes that the only way out of the stalemate towards a peaceful coexistence of the Palestinians and the Israelis is a form of memory that is neither excessive and therefore "unable to explore new possibilities of being in the future," nor forgetting, which involves both the amnesia about Jewish suffering in the past and Palestinian suffering in the present as well as "the denial of the historical connection between these two narratives of loss" (Said 1997). Said states: "The simple fact is that the Jewish and Palestinian experiences are historically, indeed organically, connected: to break them asunder is to falsify what is authentic about each. We must think our painful histories together, however difficult that may be, in order for there to be a common future." (Said 1997). In "Edward Said: 'The Last Jewish Intellectual': On Identity, Alterity and the Politics of Memory" (2006), Hochberg analyzes Said's notion of memory. While Said perceives memory as "the only valid means for creating an inclusive Israeli-Palestinian society," he also criticizes "the current dominant politics of memory as used and abused in the context of the Israeli-Palestinian conflict" (Hochberg 2006, 52). Foregrounding the importance of seeing the connection 
between the two memories of loss, Said does not underestimate the difficulty of the task.

Seven Jewish Children is Caryl Churchill's intentional engagement with the Palestine-Israel conflict. Many factors testify to this: the circumstances of writing the play, its production, the subject matter, and Churchill's reputation for being politically forthright. Written and performed within a month of Operation Cast Lead, Churchill offered free licenses for the performance to anyone, provided they allow free admission and collect donations for MAP (Medical Aid for Palestinians). Clements argues that the play's "fundraising objectives are particularly important in the light of the controversy around the decision by both the BBC and Sky to refuse to broadcast an appeal for Gaza by the Disasters Emergency Committee on 26 January 2009, citing the need for impartiality, although ITV, and Channels 4 and Five all broadcast it" (Clements 2013, 358). The Guardian's production of the play went viral on the internet, contributing its share to inflaming the debate. The short form of the play itself and the straightforward short lines are meant to make it "go viral" (Felton-Dansky 2011, 161). The critical responses to the play and the heated debate it started underline Churchill's success in making Seven Jewish Children an intervention in the politically charged conflict of Palestine-Israel. Furthermore, the subject matter of the play ventures upon what Said identifies as a difficult task: seeing the link between two memories of loss. Could the angry responses to the play be attributed to how Seven Jewish Children challenges the existing borders between the collective memories of Palestinians and Israelis?

Howard Jacobson's article 'Let's see the 'criticism' of Israel for what it really is" is not so much a critique of Seven Jewish Children as much as it is an expression of rage at what the author believes to be a rise in the wave of hatred of Israel "expressed in our streets, on our campuses, in our newspapers, on our radios and televisions, and now in our theatres" (Jacobson 2009). The site of this "hatred" is "safe cozy old easy-come easy-go England" (Jacobson 2009). The title of the article foregrounds the problematic perception of Israel and the Jews as one and the same thing. The entanglement of the political and religious identities entails that criticism of the policies of the Israeli state means "hatred" of the Jews, something which immediately invokes their painful memory of suffering. Believing the characters in the play to represent all Jews, Jacobson uses the memory of the Holocaust to level accusations of Holocaust denial: 
Berating Jews with their own history, disinheriting them of pity, as though pity is negotiable or has a sell-by date, is the latest species of Holocaust denial, infinitely more subtle than the David Irving version with its clunking body counts and quibbles over gaschamber capability and chimney sizes. Instead of saying the Holocaust didn't happen, the modern sophisticated denier accepts the event in all its terrible enormity, only to accuse the Jews of trying to profit from it, either in the form of moral blackmail or downright territorial theft. According to this thinking, the Jews have betrayed the Holocaust and become unworthy of it, the true heirs to their suffering being the Palestinians. (Jacobson 2009)

Jacobson's logic demonstrates the competitive mode of memory. Pro-Palestinian positions are interpreted as a "subtle" denial of the Holocaust where "the modern sophisticated denier" accepts the event in its enormity while accusing the Jews of profiting from it. Criticism of the political actions of Israel, as was the case during the Gaza offensive, is interpreted as an attack on all the Jews and an annulment of their history of suffering only to offer it up to their "true heirs," the Palestinians.

While Jacobson's position is a manifestation of the existing battle of memories, it also underlines the belief in the unique status of the Holocaust memory. From a memory constructed through the multidirectional logic of the writers and thinkers of the era of decolonization (such as the African American W. E. B. Du Bois and the French Marguerite Duras), the Holocaust shifted to the center of moral consciousness in the last decades of the twentieth century. It has come to assume a certain uniqueness which borders on "historical hyperbole" (Rothberg 2009, 16). In the introduction to Witness and Memory: The Discourse of Trauma (2012), Ana Douglas and Thomas A. Vogler state:

The view that the Holocaust is unique and without parallel in human history is closer to a doctrine or a dogma than to a reasoned discursive position. Its rhetorical form is usually an unargued assertion: "For Auschwitz and Treblinka there was no earlier historical analogy and there was no philosophical, or for that matter theological, frame of mind that could possibly integrate them into any system of thought" (Katz 33). [...] the Truth of the uniqueness of the Holocaust is established not by detailed comparisons with other atrocities, or by argument, but by assertions that seem to call 
for an act of faith and to make intellectual labor directed towards "understanding" not only vain, but an insult or blasphemy. It is more like a religious position than an intellectual one. (25)

Not only is the Holocaust still the primary and archetypal topic in memory studies and in arguments about the transnationalization or globalization of memory (Craps and Rothberg 2011, 517), but this "dogma" also dominates the public discourse. It has come to exercise a tyranny which censors acts of intellectual engagement or attempts at depicting analogies. Compared to the archetypal status the memory of the Holocaust has assumed, all other memories are dwarfed. Consequently, believers in the "dogma" of the Holocaust would see any connection between it and the Palestinian memory as an offense, even a "blasphemy" (Douglas and Vogler 2012, 25).

The uniqueness of the Holocaust is intricately connected to another factor which escalates the Palestinian-Israeli battle of memory, namely Zionism and how it instrumentalized the memory of the Holocaust to justify Israeli violence and injustices towards the Palestinians. In his article "Edward Said: "The Last Jewish Intellectual': On Identity, Alterity and the Politics of Memory" (2006), Hochberg states:

It is by now no secret that the Zionist leadership has systematically mobilized the memory of the Holocaust to gain exclusive control over the representation of the Israeli-Palestinian conflict. The memory of the Holocaust has played a major role in establishing the Zionist national- theological narratives of mi-galut le-geula ("from exile to redemption") and mi-shoa le-tkuma ("from the Shoah to resurrection"), and it continues to be used retrospectively to justify contemporary political injustices and violence carried out by Israel on Palestinians. (52)

Hochberg points out how Edward Said has repeatedly tackled the question of Zionist manipulation and instrumentalization of the Holocaust memory to justify the various Israeli injustices against the Palestinians. Hochberg highlights how Said believed the "heavy emotional pressure of the Holocaust" to be the main psychological obstacle in the way of a fair political examination of Palestinian loss (52). Because Zionist narratives operate from the mode of competitive memory, the emergence of another memory, let alone "a fair political examination of Palestinian loss", would be a threat. 
It is this exclusionary mode of memory which makes Jacobson perceive Seven Jewish Children and the pro-Palestinian protests against the Israeli offensive in Gaza as one and the same. It is true that both express moral outrage at the Israeli violence against civilians in Gaza. However, they employ different politics of memory. The slogans supporting Gaza such as: "Stop the Holocaust in Gaza" or "Gaza is the New Warsaw" are based on analogies of the Holocaust and Gaza, Jews, and Palestinians. These analogies, quite recurrent in responses to Israeli policies towards the Palestinians (Rothberg 2011, 531), belong to the equationcompetition quadrant of the map of memory. They do not show solidarity for both parties since they point at one as the aggressor, the other as the victim. Despite the good intentions behind them, such analogies miss the historical specificity of the Israelis as a different and more complex type of colonizer. Hochberg foregrounds Said's conviction that the colonial reality in Palestine is complicated by its encounter with the Jewish question (Hochberg 2006, 57). Hence, any attempt to understand, let alone solve the Palestinian problem entails the understanding of what it means to be the victims of the "paradigmatic victims of the twentieth-century" (Said quoted in Hochberg 2006, 57). In addition, the comparison-competition mode in the case of the Holocaust memory deprives the other party, (in this case the Palestinians), of being a site of novelty and hence of empathetic identification (Rothberg 2011, 536). When compared to the Holocaust memory, the Palestinian narrative of suffering is obliterated, its novelty dwindles.

True that Seven Jewish Children begins with the Holocaust and ends with Gaza, yet the two events are neither positioned antagonistically nor cast as similar in nature or scale. The seven scenes of the play, arranged chronologically, begin with the horror of the Holocaust, what to tell/not to tell the absent Jewish girl about what is happening. The character(s) fluctuates between fearing for the girl's life if she is discovered and not wanting to frighten her (references will be to scenes and line numbers):

Tell her it's a game

Tell her it's serious

But don't frighten her

Don't tell her they'll kill her

Tell her it's important to be quiet

[...]

Tell her it's a story

Tell her they'll go away 
Tell her she can make them go away if she keeps still

By magic

But not to sing. (1. 1-5, 16-20)

The first three scenes cover the segment of Jewish history from the Holocaust to finding a "home" (3. 5) in Palestine. The frictions with another people, which start in Scene Four, trigger the moral dilemmas of the characters which persist and escalate till the end of the play. The question of what to tell or not to tell the Jewish girls highlights the act of constructing collective memory. Despite the absence of one story, or maybe because of this absence, the questions occupy center stage.

Jacobson's article does not stop at the early scenes of Jewish suffering. What provokes him is the inner conflicts of the characters as they come in touch with the questions pertaining to the Palestinians. Using a generic language, Jacobson (2009) states:

The staccato form of the piece - every line beginning "Tell her" or "Don't tell her" - is skillfully contrived to suggest a people not just forever fraught and frightened but forever covert and deceitful. Nothing is true. Boasts are denials and denials are boasts. Everything is mediated through the desire to put the best face, first on fear, then on devious appropriation, and finally on evil.

The indefiniteness of discursive expressions such as "forever," "nothing," and "everything" convey a sense of totality and collective involvement. Using a language which generalizes and groups, Jacobson believes the characters in the play represent "a people." Hence, all Jews are "forever fraught and frightened" and "forever covert and deceitful". "Everything" they do is motivated by the desire to hide "fear," "appropriation," and "evil."

Jacobson's attitude towards the effect of fear is worth examining. While he represents a point of view of the Jew as the ultimate victim (whom the play disinherits of pity), he criticizes Seven Jewish Children for suggesting that the Jews are "forever fraught and frightened" (Jacobson 2009). Despite defending the unique victimhood of the Jews who suffered the Holocaust, Jacobson is offended by the fear suffered by the characters. He reacts to fear as if it is an accusation that should be denied, rather than the normal feeling of victims who despite finding a "home" (3. 5) failed to find safety. In Scene Six, the moral dilemma of the character(s) escalates with the questions about using the water 
for the Israeli swimming pools instead of irrigating Palestinian fields, the building of settlements and the dead boy. While the successive scenes hint at the absence of safety, the character(s) in Scene Six states it clearly:

Don't tell her they set off bombs in cafés

Tell her, tell her they set off bombs in cafés

Tell her to be careful

Don't frighten her.

Tell her we need the wall to keep us safe

Tell her they want to drive us into the sea

Tell her they don't. (6. 22-28)

Offended by Churchill's depiction of the effect of fear, Jacobson states:

Thus lie follows lie, omission follows omission, until, in the tenth and final minute, we have a stage populated by monsters who kill babies by design - "Tell her we killed the babies by mistake," one says, meaning don't tell her what we really did - who laugh when they see a dead Palestinian policeman ("Tell her they're animals [...] Tell her I wouldn't care if we wiped them out"), who consider themselves the "chosen people", and who admit to feeling happy when they see Palestinian "children covered in blood". (Jacobson 2009)

The reference here is to the last monologue in the play which has roused many an angry reaction. Compared to the previous scenes, this is the longest. Uttered by one character, the monologue reflects many views, some of which are contradictory as in: "Tell her the army has come to our defense. Don't tell her her cousin refused to serve in the army" (7. 7-8). Meanwhile, this monologue, which takes place during the Israeli offensive in Gaza, comes as a climax to the whole play and an expression of the state of precarity which is present from the first scene. Most of the six previous scenes, dealing with a major historical moment in Jewish and Israeli history underline fear, a marker of the state of precarity. Judith Butler explains that precarity, our lives depending on others most of whom remain anonymous, is the result of hegemonic power structures (Butler 2009, 14). Butler states that precarity "characterizes that politically induced condition of maximized precariousness for populations exposed to arbitrary states violence" (26). Clements states that in Seven Jewish Children: 
Churchill figures both Jewish and Palestinian lives as, in Butler's terms, 'precarious', as the language speaks consistently of the threat of death, the realities of relocation and displacement, and the problems of how to explain these to each scene's absent child. Further than this, though, the specificities of the threat - from the oppression of Jews across European history, to the displacement of Palestinians as a result of the formation of Israel and the settlement - render the lives being represented as not just precarious, but existing in a state of extreme precarity. $(2013,360)$

The effect of fear is often present in the language of the characters which either refers directly to fear and states of fright or speaks of specific threats. In other times, fear seems like an undercurrent that is present but invisible, as shown in the lines from Scene Four where the Jews gained a home and the character is considering the question of Palestinian presence in this land: "Don't tell her home, not home, tell her they're going away/ Don't tell her they don't like her/ Tell her to be careful" (4. 7-9).

It is only in two scenes (out of seven) that the imperative "Don't frighten her" or "Tell her not to be frightened" vanishes. Fear is absent in Scene Three, leaving Europe to go to what is referred to in Scene Four as "our promised land" (4. 20). At this point the dream of having a home is not yet disturbed by the challenges posed by the reality of Palestinian presence in this land. Scene Five, which depicts Israeli military victory in 1967, is also free of fear. This is the only segment in the play which hosts affirmative statements uninterrupted by negation. It is also the shortest scene. Made of only six lines which look like a brief and sudden flash of light in a longer history of fear. The following lines make the whole scene:

Tell her we won

Tell her her brother's a hero

Tell her how big their armies are

Tell her we turned them back

Tell her we're fighters

Tell her we've got new land. (5. 1-6)

Other than these two scenes which are free of fear, the state of precarity builds up towards the explosive moment of Scene Seven:

Don't tell her how many of them have been killed 
Tell her the Hamas fighters have been killed

Tell her they're terrorists

Tell her they're filth

Don't

Don't tell her about the family of dead girls

Tell her you can't believe what you see on television

Tell her we killed the babies by mistake

Don't tell her anything about the army

Tell her, tell her about the army, tell her to be proud of the army. Tell her about the family of dead girls, tell her their names why not, tell her the whole world knows why shouldn't she know? tell her there's dead babies, did she see babies? tell her she's got nothing to be ashamed of. Tell her they did it to themselves. Tell her they want their children killed to make people sorry for them, tell her I'm not sorry for them, tell her not to be sorry for them, tell her we're the ones to be sorry for, tell her they can't talk suffering to us. Tell her we're the iron fist now, tell her it's the fog of war, tell her we won't stop killing them till we're safe, tell her I laughed when I saw the dead policemen, tell her they're animals living in rubble now, tell her I wouldn't care if we wiped them out, the world would hate us is the only thing, tell her I don't care if the world hates us, tell her we're better haters, tell her we're chosen people, tell her I look at one of their children covered in blood and what do I feel? tell her all I feel is happy it's not her.

Don't tell her that.

Tell her we love her.

Don't frighten her. (7. 9-36)

A turning point takes place towards the middle of the monologue. Before "Tell her, tell her about the army" (7. 17), the voice juxtaposes contradictory views, something which underlines the moral confusion of the character and the difficult choices facing him/her. Telling the girl about the Hamas fighters as "terrorists" and "filth" (17. 10-12) is certainly easier than telling her about "the family of dead girls" (7. 17-18). However, deciding to tell the absent child about the dead Palestinian children does not seem to be much of a choice since "the whole world knows why she shouldn't she know?" (7. 18-19). The character realizes the girl would come to know anyways. A turning point is noted as the character utters a succession of affirmative imperatives. The disappearance of 
contradictory opinions together with the frantic repetition of "tell her" reveals a state of anguish. There is fear and anguish lurking behind the character's insistence there is nothing to be ashamed of, the refusal to show sympathy for the dead children (because it is the Palestinians who "want their babies killed to make people sorry for them" (7. 20-21), and even behind the laughing at the image of the dead policemen. This fear is related to both the present state of precarity as well as the old Jewish suffering. Could it be that the images of death and destruction in Gaza and the image of Palestinian children covered in blood trigger the character's older trauma? This would understandably lead the character to comment on the image of the dead Palestinian girl by saying "tell her all I feel is happy it's not her." If the effect of fear (vehemently denied by Jacobson) is not perceived here, the character would be seen as a monster.

\section{"Each is the other"}

Although the play comprises Jewish characters only, the absent Palestinians are present as an entity referred to and in conflict with. Clements argues that "Churchill's creation of a set of Jewish and Israeli voices and imaginary children simultaneously pushes the Palestinian perspective out of the picture and, by its very omission, highlights its absence" (Clements 2013, 360). Absent from the physical stage, the Palestinians are present not just as the other party in the conflict and the trigger for the characters' moral dilemmas, but they could also be perceived as a "psychic factor" in Jewish identity. Said states:

$[\mathrm{N}] \mathrm{o}$ Arab today has an identity that can be unconscious of the Jew, that can rule out the Jew as a psychic factor in the Arab identity; conversely, I think, no Jew can ignore the Arab in general, nor can he immerse himself in his ancient tradition and lose the Palestinian Arab and what Zionism has done to him. The more intense the modern struggles for identity, the more attention is paid by the Arab or the Jew to his chosen opponent, or partner. Each is the other. $(1974,3)$

Said's statement suggests that the construction of each of the two collective memories cannot take place without the existence of the two "partner[s]." If this "chosen" partnership is not realized by both parties, the cycle of violence between Palestinians and Israelis will not come to an end. In dramatizing Said's statement "Each is the other," Churchill's play crosses over the clearly demarcated border of two rival memories and juxtaposes the two narratives of 
suffering. None obliterates the other. In achieving this end, Seven Jewish Children perceives Palestinian lives as equally grievable. In Judith Butler's discussion of the question of grievability and mourning, not as a goal of politics but as an important necessity without which "we lose that keener sense of life we need in order to oppose violence" (Butler 2004, XVIII), she poses questions which apply to the Palestinians: "[w] ho counts as human? Whose lives count as lives? [...] What makes for a grievable life?" (Italics in original; Butler 2004, 20). Speaking of a "hierarchy of grief," Butler explains that: "[c]ertain lives will be highly protected, and the abrogation of their claims to sanctity will be sufficient to mobilize the forces of war. Other lives will not find such fast and furious support and will not even qualify as "grievable" (Butler 2004, 32). Among the examples of lives which are not equally and fully grievable is the case of Palestinians. Butler asks:

Why is it that Israeli and Palestinian deaths are not viewed as equally horrible? To what extent has the very refusal to apprehend Palestinian deaths as "slaughter" produced an immeasurable rage on the part of Arabs who seek some legitimate recognition and resolution for this continuing state of violence?" $(2004,14)$

Rothberg reiterates the same opinion when he affirms that "[i]t is surely true, at least in the United States, that a great inequity in the distribution of grievability exists whereby Palestinians are routinely rendered as less than fully valued human lives (Rothberg 2011, 532).

Churchill manages to evoke the grievability of Palestinian lives by means of a technique which leaves plenty of space for the audience to become witnesses and collaborators in the making of meaning. The characters are graphically sketched as family members discussing what to tell/not tell the Jewish girls. No gender, age or character traits are specified. Lines are not allocated to specific characters. Hence, any number of lines could be uttered by one or many voices. And any of the lines could be said in different tonalities eliciting different responses from the audience. Such technique leaves the audience plenty of room to bring in their own histories and positions to fill in the spaces of affect. Malone states that: "[t]he dramaturgical strategy of inviting audiences to be critically engaged in processing the material presented confronts them with a set of moral choices" (2013/2014,7). Churchill implicates the audience.

Bringing forth the grievability of Palestinian lives achieves an objective sought lately by many thinkers and intellectuals interested in indigenous, 
minority, and colonial histories, namely, decentering the memory of the Holocaust. The act of decentering "does not mean relativization of the historical facts of the Nazi genocide," but rather that "working through the implications and particularities of genocides needs to be separated from a discursive sacralization of the Holocaust that legitimates a politics of absolutism" (Rothberg 2011, 540). Many of the intellectuals challenging the uniqueness of the Holocaust:

Have argued that, while it is essential to understand the specificity of the Nazi genocide (as of all events), separating it off from other histories of collective violence - and even from history as such-is intellectually and politically dangerous. The dangers of the uniqueness discourse are that it potentially creates a hierarchy of suffering (which is morally offensive) and removes that suffering from the field of historical agency (which is both morally and intellectually suspect). (Rothberg 2009, 17)

Challenging the "hierarchy of suffering," Seven Jewish Children outraged many. Critics such as Christopher Hart and Jeffrey Goldberg were offended by Churchill's presentation of Palestinian lives' grievability. For those who believe in memory as "a zero-sum game" (Rothberg 2009, 26), such comparisons would mean but one thing: "disinheriting" the Jews of pity (Jacobson 2009).

\section{Memories in Continuum}

Although Seven Jewish Children is written out of moral outrage at the Israeli violence in Gaza, it neither denies the Jews their past suffering nor their present victim status. Depicted as the perpetrator in the Gaza offensive, the Israelis carry a history of Jewish victimhood that is multilayered and complex. Seven Jewish Children approaches the Palestinian question with the realization of "what it means to be the victims of the paradigmatic victims of the twentieth-century" (Said quoted in Hochberg 2006, 57). Gurz'ev and Pappé (2003) reiterate the same opinion when they state that: "[ $\mathrm{t}]$ he Palestinian cause is strengthened not by denying the Holocaust, or disregarding or minimizing it, but rather by showing the full magnitude of its evil and horror while asserting that its ultimate victim is the Palestinian through his systematic victimization by the victims of the Holocaust (103). Churchill's awareness of the "trajectory of trauma" (Hochberg 2006, 53) connecting the Israelis and Palestinians puts forth the 
perception of two peoples inextricably connected through their suffering as well as their struggle over land and memory.

Collective memories are not fixed because they are always articulated from a present which is in a constant state of flux, hence their openness for reconstruction and alteration. In the context of the Palestinian-Israeli conflict, long dominated by a memory discourse of symmetry and competition, a multidirectional discourse is a more democratic route towards the coexistence of two peoples who were "brought together by the contingencies of history" (Barsamian and Said 2003, 147). Stef Craps (2014) believes Seven Jewish Children to be an example of "how art can bear witness to and address some of the most important issues of our day in a serious and sensitive manner" (18081). Churchill achieves this end by engaging the memories of Palestinians and Israelis in a multidirectional way. Examined through Rothberg's map of memory with its two axes of competition and affect, the play falls within the equationsolidarity quadrant. Although there are two antagonistic parties engaged in a battle, the victim status of each is depicted. The Hamas fighters throw bombs on Israeli civilians and the Israeli army, which provided a safe place for the Jews, and kill Palestinian children in Gaza. The suffering of the Jews, which was supposed to end after finding "a home," continues in the state of precarity and the moral dilemmas which make the backbone of the play.

Although cultural memory and discourses on the past are not solely capable of redressing injustices, "they can create arenas where injustices are recognized and new frameworks are imagined that are necessary, if not sufficient, for their redress" (Rothberg 2011, 538). Imagining the Palestinian and the Israeli memories in a continuum stretching from the Holocaust till Gaza, Seven Jewish Children helps in the creation of arenas where justice might be realized.

\section{Works Cited}

Barsamian, David and Edward W. Said. 2003. Culture and Resistance:

Conversations with Edward Said. Cambridge: South End Press. Billington, Michael. 2009. "Seven Jewish Children.” The Guardian, February 11. https://www.theguardian.com/stage/2009/feb/11/seven-jewish-children. Butler, Judith. 2009. Frames of War: When is Life Grievable? London: Verso. -----. 2004. Precarious life: The Powers of Mourning and Violence. London: Verso.

Churchill, Caryl. 2009. Seven Jewish Children: A Play for Gaza. London: Nick Hern Books. 
https://graphics8.nytimes.com/packages/pdf/world/SevenJewishChildren.pdf.

Clements, Rachel. 2013. "Framing War, Staging Precarity: Caryl Churchill's Seven Jewish Children and the Spectres of Vulnerability." Contemporary Theatre Review, 23 (3): 357-367.

http://dx.doi.org/10.1080/10486801.2013.806317.

Craps, Stef. 2014. "Holocaust Memory and the Critique of Violence in Caryl Churchill's Seven Jewish Children: A Play for Gaza." In The Future of Testimony: Interdisciplinary Perspectives on Witnessing, edited by Jane Kilby and Antony Rowland, 179-192. New York and London: Routledge.

Craps, Stef and Michael Rothberg. 2011. "Introduction: Transcultural Negotiations of Holocaust Memory." Criticism 53, no.4 (Fall): 517-521.

Darwish, Mahmoud. 1973. Yawmiyyat al-huzn al-'adi (Journal of Ordinary Sorrows). Beirut: Markaz al-Abhath, Munazzamat al-Tahrir alFilastiniyyah/al Mu'assash al-'Arabiyyah lil-Dirasat wa-al-Nashr.

Douglass, Ana and Thomas Vogler. 2012. Witness and Memory: The Discourse of Trauma. New York and London: Routledge. ProQuest Ebook Central. http://ebookcentral.proquest.com/lib/pitt-ebooks/detail.action?docID=1075408.

Du Bois, W. E. B. 1952. "The Negro and the Warsaw Ghetto." Jewish Life, (May): 14-15.

Felton-Dansky, Miriam. 2011. "Clamorous Voices: Seven Jewish Children and Its Proliferating Publics." TDR: The Drama Review 55, no. 3 (Fall):156-64. Project MUSE.

Goldberg, Jeffrey. 2009. "Caryl Churchill Advances Demonization of the Jews." The Atlantic, March 26.

https://www.theatlantic.com/international/archive/2009/03/-quot-carylchurchill-advances-demonization-of-jews-quot/9829/.

Gur-Ze'ev, Ilan and Ilan Pappé. 2003. "Beyond the Destruction of the Other's Collective Memory: Blueprints for a Palestinian/Israeli Dialogue.” Theory, Culture and Society 20 (1): 93-108.

Hochberg, Gil Z. 2006. "Edward Said: 'The Last Jewish Intellectual': On Identity, Alterity and the Politics of Memory." Social Text 24, no. 2 (Summer): 47-65. https://read.dukeupress.edu/social-text/articlepdf/24/2(87)/47/513621/st87-05_hochberg.pdf.

Jacobson, Howard. 2009. 'Let's See the 'Criticism' of Israel for What It Really Is.” The Independent, February 18. http://www.independent.co.uk/voices/ commentators/howard-jacobson/howard-jacobson-letrsquos-see-thecriticism-of-israel-for-what-it-really-is-1624827.html. 
Malone, Niamh. 2013/2014. “'To Tell or to Question?' Caryl Churchill's Seven Jewish Children: Theater as Witness to the Human Costs of Conflict." Kritika Kultura 21 (22): 1-10.

Mufti, Aamir. 2000. "Auerbach in Istanbul: Edward Said, Secular Criticism, and the Question of Minority Culture." In Edward Said and the Work of the Critic: Speaking Truth to Power, edited by Paul A. Bove, 253. Durham: Duke University Press.

Rocamora, Carol. 2009. "The storm over Caryl Churchill's 'Seven Jewish Children': The Power of Theater: Eight Minutes about Seven Jewish Children." Broad Street Review, March 16.

https://www.broadstreetreview.com/theater/caryl_churchills_seven_jewish_ children\#.

Rothberg, Michael. 2011. "From Gaza to Warsaw: Mapping Multidirectional Memory." Criticism 53, no. 4 (Fall): 523-548.

-----. 2009. Multidirectional Memory: Remembering the Holocaust in the Age of Decolonization. Stanford: Stanford UP.

Said, Edward W. 1999. "Truth and Reconciliation." Al-Ahram Weekly, April 14. 1997. "Bases for Coexistence." Al-Ahram Weekly, November 15.

----. 1974. "Arabs and Jews." Journal of Palestine Studies 3 (2), (January): 314. https://online.ucpress.edu/jps/article/3/2/3/53438/Arabs-and-Jews

UN Human Rights Council. 2009. "Human Rights in Palestine and Other Occupied Arab Territories: Report of the United Nations Fact-Finding Mission on the Gaza Conflict." October 28.

https://www.un.org/ruleoflaw/blog/document/human-rights-in-palestineand-other-occupied-arab-territories-report-of-the-united-nations-factfinding-mission-on-the-gaza-conflict/. 